Journal of the British Association for Chinese Studies, Vol. 8 (2), July 2018 ISSN 2048-0601

(C) British Association for Chinese Studies

\title{
The EU and China, 2006 to 2016: A Clash Between Interests and Values
}

Kerry Brown

King's College London

In the last decade, while undergoing its own reform through the Lisbon Treaty in 2009 which created a designated foreign affairs body across the 28 member states, the European External Action Service (EEAS), the European Commission has also produced two major communications on relations with the People's Republic of China. The first, in 2006, was issued at a time when the European Union (EU) was just recovering from its failure to lift the arms embargo on China, and was being criticised by Beijing because it had not accorded market economy status to a country that had become its largest trading partner. The second came out in 2016, at a time when the relationship had settled into a more pragmatic mould, though the continuing refusal to grant market economy status still rankled with the Chinese partners.

This essay will look in particular at the history of the relationship, and the ways in which this is reflected in the language in the two communications on the specific issue of values and defence of human rights. Defence of these have been, after all, a key part of the European project since its earliest period. It is written into its current constitution-to defend and promote rule of law, human rights and associated freedoms. How has the EU's internal understanding of this key area developed over the period from 2006 to 2016, when it itself was undergoing crisis and transformation, and China was also rapidly developing, often in very unexpected ways? 


\section{Historic Context}

Separate states in Europe had diplomatic relations with the People's Republic of China almost from its establishment in 1949. Great Britain, in particular, in order to defend its interests in the then colony of Hong Kong, was amongst the first in what was then Western Europe to create relations, in 1950, and was followed by Sweden, Denmark, Finland and Norway the same year. France was to follow in 1964, with the remainder of the major European countries following in the 1970s and 1980s.

The evolution of the European Steel and Iron Zone to the European Economic Community (EEC), created by the Treaty of Rome in 1957, meant that by 1975 there were enough member states to formally create diplomatic relations on a multilateral basis with the People's Republic. This was bolstered by the rapprochement between the USA and China from 1972 that saw a diplomatic relaxation clearing the way for more parties to seek formal links with Beijing.

The most significant date after this was the signing in 1985 of a framework agreement, the "Trade and Cooperation Agreement" between the two powers-one which, as its title states, largely focussed on economic, transactional issues (EEC, 1985). Despite this narrowness, the 1985 agreement remains, to this day, the foundation of the legal relationship between the two entities. It reads very much like a standard trade agreement, with provision for tariff-free access for certain classes of goods and services. At no point are social or political values or aspirations towards China for legal changes mentioned. This is unsurprising; in 1985 the EEC was much more an economic concept than driven by political norms and values.

With the implementation of the Maastricht Treaty from 1992 that created the European Union (EU), a host of new concepts occurred. The EU became a much bolder and wider endeavour than the EEC, with significant parts of the treaty agreed that year embracing social and political themes. With the political changes happening in the rest of the world, from the fall of communist governments in Eastern Europe in 1989 to the collapse of the Soviet Union in 1991, the EU became part of a move to promote liberal 
democratic government models and procedures. The EU, along with the US, set itself at the heart of this mission to embed multi-party liberal democratic norms across the rest of the world. Its trade and aid were related to the support of these.

Around this time, after the brutal suppression of a rebellion in Tiananmen Square in June 1989 by the Chinese government, the desire was to engage with China in the hope that it would ultimately change into a Western-style democracy. Such an attitude was best exemplified by the Clinton presidency, when Bill Clinton visited Beijing and stated to the then President Jiang Zemin that China had been on the "wrong side of history" because of its stance on human rights since 1989.

The EU in this way became a major normative power, one which promoted a specific liberal values agenda. This phenomenon reached its apogee in the mid-2000s. It was around this time that writers like the British foreign policy commentator Mark Leonard were able to speak of the Union as a major model of a rules-based, enlightened political power (Leonard, 2005) Following the Colour Revolutions in the countries which had once been part of the USSR in the middle part of this decade, this sense of confidence strengthened. Hand and hand with a more zealous and activist leadership on foreign affairs in the US under George W Bush, the notion of spreading democracy as part of the EU's mandate was accompanied by an era in which the membership of the Union started to extend to new accession countries like Poland and Romania, increasing the number of member states to 27 by the end of the decade.

This makes the timing of the 2006 document, "EU China: Closer Partners, Growing Responsibilities" (Commission of the European Communities, 2006), very significant. Issued at a time when EU economic growth and political confidence was strong, it came only two years after the abortive attempt by the member states to lift the arms embargo imposed in 1989 on military and dual-use equipment sales to China. This was a symbolic move rather than one of practical import, largely because most sensitive technology was covered under member state law. Even so, the US vehemently opposed the idea, meaning that despite strong Chinese protests, the idea was dropped. As an extra irritant, the EU continued to refuse to convey market economy status to 
China, and leaders of specific member states continued to pressurise China on human rights and to allow top level meetings between the Dalai Lama, the exiled Tibetan religious leader, and their heads of government or state.

"Closer Partner: Growing Responsibilities" sets out the core areas of mutual interest and potential cooperation between the two powers as: (1) supporting China's transition towards a more open and plural society, (2) sustainable development, (3) trade and economic relations, (4) strengthening bilateral cooperation, and (5) international and regional co-operation. Under the first few, the language is strikingly confident:

Democracy, human rights and the promotion of common values remain fundamental tenets of EU policy and of central importance to bilateral relations. The EU should support and encourage the development of a full, healthy and independent civil society in China. It should support efforts to strengthen the rule of law-an essential basis for all other reform.

At the same time, the EU will continue to encourage full respect of fundamental rights and freedoms in all regions of China; freedom of speech, religion and association, the right to a fair trial and the protection of minorities call for particular attention-in all regions of China. The EU will also encourage China to be an active and constructive partner in the Human Rights Council, holding China to the values which the UN embraces, including the International Covenant on Civil and Political Rights.

The twice-yearly human rights dialogue was conceived at an earlier stage in EU-China relations. It remains fit for purpose, but the EU's expectations-which have increased in line with the quality of our partnership-are increasingly not being met. The dialogue should be: more focussed and resultsoriented, with higher quality exchanges and concrete results; more flexible, taking on input from separate seminars and 
sub-groups; better co-ordinated with Member State dialogues (Commission of the European Communities, 2006).

The Communication from a decade later went under the more prosaic title "Elements for a New EU Strategy on China". A longer document than the one from 2006, it occurred at the end of ten years of radical change internally and externally, and on the same day as the UK voted to exit the EU in a national referendum. This was an event which was symbolic of the changes that had occurred to erode the Union's sense of confidence in the previous few years. The most important contributing factor to this was the great financial crisis starting in 2008, and the problems which beset the Eurozone from 2009, calling into question some of the fundamental tenets of the whole EU project, damaging much of its economic prowess and creating a sense of almost perpetual crisis. The Lisbon Treaty in 2009 had bravely attempted to create a closer sense of Union, with a new European External Action Service (EEAS), referred to above, a kind of EU diplomatic service, a presidency, and a clearer shared political structure set up.

But by 2015, there were a series of unprecedented issues, from a wave of migrants coming from war-torn Syria, of whom over a million came to Germany alone that year, to continuing issues over stagnant growth, and the rise of populist, nationalist parties coming to power. These remained issues three years later when a major migrancy summit was held in June 2018 to try to handle issues which had been appearing around this time. The EU seemed to be increasingly vulnerable, and far from promoting its sense of values abroad, was largely attempting to at least maintain some of them back in Europe. All of this happened in a context in which China under Xi Jinping was able to maintain relatively high growth, but also was becoming much more assertive in its foreign policy in the Asian region while ratcheting up repression and autocratic governance back in China. In 2015 alone, over 250 rights lawyers were detained, with some given lengthy jail sentences (Wielander, 2017). Never had it seemed more challenging to be a supporter of political change and reform in the People's Republic. 
That was the background against which the 2016 "Communication on China" was articulated. The issues addressed again are values and rights. To quote from the "Principles of Engagement" section of the document:

The fundamental principle of the EU's relationship with China is that it should be based on reciprocal benefit in both political and economic terms.

- The EU's engagement with China should be principled, practical and pragmatic, staying true to its interests and values. It will continue to be based on a positive agenda of partnership coupled with the constructive management of differences.

- $\quad$ EU Member States' engagement with China must comply with EU laws, rules and policies.

- The EU expects China to assume responsibilities in line with the benefits it draws from the rules-based international order.

- The promotion of human rights will continue to be a core part of the EU's engagement with China, with the well-being of citizens and respect for international obligations at the centre of its approach. The EU will hold China to account for its human rights record.

- The EU confirms its "One China" policy.

- The EU should continue to develop its relations with Taiwan and to support the constructive development of cross-Strait relations.

- The EU should support the continued implementation of "One Country, Two Systems" in Hong Kong and Macao.

- EU policy-making on China should take full account of the EU's close relationships with the US and other partners (European Commission, 2016: 5).

There are a number of observations to make about the difference in tone, context and content of these two articulations of rights issues between 2006 and 2016. 
Firstly, the 2006 entry is highly generic. It does not speak about specifics, beyond support for rule of law, and the associated rights that flow from political, social and cultural freedoms. This indicates a level of confidence that the rationale and basis for these rights are understood, universally applicable, and that they should, and can, be urged on political cultures as different as that of China's. The 2016 Communication, on the other hand, while recognising the importance of rule of law, is much more specific in its articulation of key areas and expected outcomes. It also stresses pragmatism in its first tiret. It is clear that this document is an evolution of the earlier one, and shows the development of a more complex, nuanced situation in which to locate the rights dialogue between China and the EU.

Secondly, the 2006 entry occurs in a context in which the imperative is to "work with China to help it with its internal reforms" towards becoming a more pluralistic society, and one that is, though this is not explicitly stated, on the way to becoming more broadly democratic. It is true that in 2006, there was greater confidence in the need for China to adopt political models more akin to those found in Europe or North America. However, with the 2008 financial crisis and the Eurozone's issues enveloping the EU thereafter, this confidence was dented. By 2016, unexpected outcomes from democracies like Brexit in the UK, and the election of Donald Trump as president of the USA later that year, meant that the high confidence in the international liberal democratic order had been eroded for many.

Under Xi Jinping, in China since 2012, the Communist Party had set itself even more aggressively against attempts to see it reform and become like polities elsewhere. This was best exemplified in the "Document No 9" issued by the Propaganda Department of the Chinese Communist Party Central Committee in early 2013, which stipulated that academics in class should not be teaching universalism, constitutionalism and other values which were dismissed as Western (China File, 2013). This means that the 2016 document, even in its values section, is keener to stress reciprocity. This appears clearly in the statement that at heart the relationship between the two needs to be "principled, practical and pragmatic, staying true to its interests and values. It will continue to be based on a positive agenda of partnership coupled with the constructive management of differences." Differences in this context are 
simply to be accepted and managed, rather than resolved in the EU's favour. This is a marked change in tone, and reflects the falling back from the more assertive, confident and perhaps, in hindsight, naïve tone of the 2006 Communication.

Thirdly, the 2006 document does express frustration at the lack of progress in human rights dialogues, set up between the EU and China from the 1990s, to create a means of addressing and then discussing differences over rights. By 2016, the various dialogues had been compromised, so that many analysts felt they lacked legitimacy and needed to be scrapped. In the words of one report by German scholar Katrin Kinzelbach, they only served to excuse European leaders from directly talking of sensitive issues by outsourcing them to experts, officials and lower level functionaries (Kinzelbach, 2014). In many ways, the journey from 2006 to 2016 for the Chinese government had been one during which it became less keen or willing to put itself in a position of hearing lectures from foreign leaders on values issues.

Finally, the 2006 document expresses the hope that member states would be able to co-ordinate their China policy more effectively. However, over the course of this period, clear divisions about how to handle values issues with China mapped out the distinct positions of countries within the EU-ranging from a more emollient attitude on Tibet, Taiwan and treatment of dissidents by Malta, to a sometimes harder line by the Czech Republic. In some ways, the 2016 document, which has a far more detailed section on economic sustainability and other issues, shows the ways in which while values still figured, for the EU in general and member countries in particular, they had to be situated in a more complex range of considerations. This growth of complexity is clear from the two entries. While the 2016 Communication sets out that "it will hold China to account for its human rights record", it also shows that this occurs in a context in which defence of the global rules-based trade and governance order offers the best tangible bet to bring China onside. This sense of tactical engagement, working in areas where there was now clear common interest, is unpacked in the rest of the 2016 document, which is twice the length of the 2006 one. 
The 2006 Communication stated as one of its three objectives that the main priority was to see a relationship in the area of values, rights and political dialogue with China which was "more focussed and results-oriented, with higher quality exchanges and concrete results". It is true that there had been mutual learning over this period, which is recognised in the greater detail expressed in the 2016 document. By 2016, a harder attitude towards Westernstyle political reform in China was accompanied by a greater circumspection within the EU. The EU's awareness of more shared concerns around sustainability, the need to create better quality growth in the EU, the need for investment from China, and access to growth opportunities within the Chinese market meant that values and rights, while still figuring, competed within a marketplace of other ideas and imperatives. This explains the references to Hong Kong, Taiwan and the more geopolitical issues that end the 2016 Commission document. The differences between the 2006 and 2016 documents mark a journey towards greater pragmatism on the part of the EU, and a possible recognition of the more complex world both China and the EU exist in, and the more complex links with each other within it-an issue that has only been reinforced with the arrival of Donald Trump as president of the US, and the rising prominence globally of China under Xi Jinping.

\section{References}

China File (2013), "Document Number 9: A ChinaFile Translation", November 8, available at: http://www.chinafile.com/document-9-chinafiletranslation (accessed 04.07.2018).

Commission of the European Communities (2006), "EU China: Closer Partners, Growing Responsibilities", October 24, available at: http://trade.ec.europa

.eu/doclib/docs/2006/october/tradoc_130875.pdf (accessed 19.11.2016).

EEC (1985), "COUNCIL REGULATION (EEC) No 2616/85 of 16 September 1985 concerning the conclusion of a Trade and Economic Cooperation Agreement between the European Economic Community and the People's Republic of China", available at: https://eur-lex.europa.eu/legalcontent/EN/TXT/?uri=celex:31985R2616 (accessed: 04.07.2018). 
European Commission (2016), "Joint Communication to the European Parliament and the Council: Elements for a New EU Strategy on China", June 22 2016, available at: http://eeas.europa.eu/archives/docs/china/docs/joi nt_communication_to_the_european_parliament_and_the_council_-_ele ments_for_a_new_eu_strategy_on_china.pdf (accessed 19.11.2016).

Kinzelback, Katrin (2014), The EU's Human Rights Dialogue with China: Quiet Diplomacy and its Limits, London: Routledge.

Leonard, Mark (2005), Why Europe will Run the 21st Century, London: HarperCollins.

Wielander, Gerda (2017), "The Dangers of Taking Responsibility and Acting on One's Conscience in 21st Century China: A Review Essay of Xu Zhiyong's To Build a Free China: A Citizen's Journey", Journal of the British Association for Chinese Studies 7(2): 112-121.

Kerry Brown is Professor of Chinese Politics and Director of the Lau China Institute

at

King's

College London. 
11 Kerry Brown 